\title{
Production of biodiesel from neem seed oil
}

\author{
S. K. Banik ${ }^{1 *}$, M. A. Rouf ${ }^{1}$, T. Rabeya ${ }^{1}$, M. Khanam ${ }^{1}$, S. I. Sajal ${ }^{2}$, S. B. Sabur ${ }^{2}$ and M. R. Islam ${ }^{2}$ \\ ${ }^{I}$ Institute of Fuel Research and Development, Bangladesh Council of Scientific and Industrial Research, Dr. Qudrat-i- Khuda \\ Road, Dhaka-1205, Bangladesh \\ ${ }^{2}$ Department of Mechanical Engineering, Rajshahi University of Engineering and Technology, Rajshahi-6204, Bangldesh
}

Received: 31 October 2017

Revised: 14 December 2017

Accepted: 31 January 2018

DOI: http://dx.doi.org/10.3329/bjsir.v53i3.38268

\begin{abstract}
Neem oil was extracted from neem seeds by mechanical extraction method. Yield of oil was $21.32 \%$. The physicochemical properties of the extracted oil were studied in detail. The oil corresponds to diesel except acid value (14.21\%) and sulphur content. Acid esterification was performed to reduce the acid value which was followed by transesterification to produce biodiesel. The conditions of the transesterification of the oil were optimized and were found to be $20 \%$ methanol and $1.0 \% \mathrm{NaOH}$ at $60{ }^{\circ} \mathrm{C}$ for $90 \mathrm{~min}$. The optimum yield of biodiesel was $98 \%$. Finally, the performance study in a diesel engine was conducted with diesel and biodiesel blends. The brake thermal efficiency for $5 \%$ blend of biodiesel was $16.67 \%$ for brake power of $0.79 \mathrm{KW}$.
\end{abstract}

Keywords: Neem oil; Transestrification; Biodiesel; Thermal efficiency; Brake power

\section{Introduction}

Energy has been the synonym of economic development of any country in the current world. But the current fossil fuel based economy suffers from the issue of sustainability because of environmental impacts, economic dependence and energy security. The production and consumption of fossil fuels have raised the concentration of $\mathrm{CO}_{2}$ in the atmosphere to cause a severe impact on the environment (Westermann et al., 2007). At present $86 \%$ of the world energy consumption and almost $100 \%$ of the energy needed in the transportation sector are met by fossil fuels (Dorian et al., 2006). One-fifth of the global $\mathrm{CO}_{2}$ emissions are created by transport sector (Goldemberg, 2008), which accounts for $60 \%$ of global oil consumption (Anonymous, 2008). Around the world there were about 806 million cars and light trucks on the road in 2007 (Banik et al., 2015). These numbers are projected to increase by 1.3 billion by 2030 and to 2 billion vehicles by 2050 (Banik et al., 2015). These growths will affect the stability of ecosystems and global climate as well as global oil reserves (Balat, 2009). The biofuels of recent days can resolve the issues of sustainable development, energy security and reduction of green house gas emissions (Sylvester et al., 2013). As an alternative to petroleum based transportation fuels, biodiesel is a suitable renewable substitute for petroleum based diesel. Biodiesel is a methyl or ethyl ester made from renewable biological sources such as vegetable oils (both edible and non edible), recycled waste vegetable oils and animal fats (Wilson, 2010). Biodiesel reduces net carbon-dioxide emissions by $78 \%$ on a lifecycle basis when compared to conventional diesel fuel (Carvalho et al., 2011). Emissions such as total hydro carbons and $\mathrm{CO}$ are usually found to be significantly low with biodiesel as compared to petroleum diesel. This may be due to more complete combustion caused by the increased oxygen content in the flame coming from the biodiesel molecule (Hemant et al., 2011). The annual demand of diesel fuel in Bangladesh is increasing tremendously.

\footnotetext{
*Corresponding author e-mail: sujit.bcsir@gmail.com
} 
To meet the growing demand, we are totally dependent on foreign countries and large amount of foreign currencies are spent to import the diesel fuel. If biodiesel is used to some extent in place of diesel fuel, a vast amount of foreign currencies will be saved. Hence, we pointed our eyes on the production of biodiesel from non edible neem seed oil. Literature shows that the yield of oil from neem seed is about $15.4 \%-24.5 \%$ (Kaura et al., 1998). Neem plant is available in many parts of the world including Bangladesh and is very cheap compared to other sources. The non-edible renewable neem seed oil can play a vital role as a substitute to diesel fuel. The climate and soil condition of Bangladesh is also suitable for the cultivation of this plant. If the developed process is scaled up to commercial levels, then excellent business opportunity will be offered by the biodiesel and this could be a major step towards the creation of an eco friendly transportation fuel. By increasing neem tree plantation in Bangladesh, we can meet our demand. Finally, the by-product (glycerin) of trans esterification can also be used in the soap industry. The present investigation includes: preparation of biodiesel from neem seed oil, optimization of different parameters for maximum biodiesel production, determination of properties of neem seed oil and prepared biodiesel, comparison of the fuel properties of conventional diesel with prepared biodiesel and performance study of the biodiesel in diesel engine.

\section{Materials and methods}

\section{Oil extraction from Neem seeds}

To prepare the seeds for oil extraction, seeds were heated in full sunlight on a black plastic sheet for several hours. The seeds were heated, but not burnt. This process breaks down the cells that contain the oil, allowing the oil to flow out more easily. The heat also liquefies the oil, which improves the extraction process. Oil is then extracted by mechanical extraction method. Conversion of oil from seed is $21.20 \%$. After extraction, fuel properties of crude neem seed oil were determined.

\section{Production of biodiesel}

The acid value of the reaction mixture was determined by a standard acid base titration method using a standard solution of $1.0 \mathrm{M} \mathrm{KOH}$ solution. Prior to transesterification, acid esterification of the oil was required to reduce the free fatty acid $(14.32 \%)$. The methanol and catalyst (conc. $\mathrm{H}_{2} \mathrm{SO}_{4}$ ) mixture was then charged into a two-necked closed reaction vessel and the raw oil was added. The reaction time and temperature was $1 \mathrm{hr}$ and $60^{\circ} \mathrm{C}$ respectively. The optimum condition for reducing the free fatty acid of neem oil below $2 \%(1.6 \%)$ was obtained by $0.58: 1$ methanol to oil ratio,
$0.75 \% \mathrm{v} / \mathrm{v}$ sulphuric acid to oil volume. After acid esterification, trans esterification was done with $\mathrm{NaOH}$ catalyst in a two -neck round bottom flask equipped with condenser and magnetic stirrer. The reaction time was varied from $1 \mathrm{hr}$ to $2 \mathrm{hrs}$ and temperature was around $60^{\circ} \mathrm{C}$. After completion of trans esterification, methyl ester was separated from mixture of methyl ester and glycerin. The mixture was taken in a separating funnel and left for 16 hours. The mixture was separated in two layers, biodiesel as the top layer and glycerin as bottom layer. Glycerin layer was withdrawn and required product was obtained. Washing of biodiesel was necessary to remove the soluble components. Hot water was sprayed on top of biodiesel. Then it was allowed to settle down. The product was dried using a vacuum evaporator at $80{ }^{\circ} \mathrm{C}$ and pressure was 180 atm. After drying the pure product became clear.

\section{Characterization of crude neem oil and produced biodiesel}

All the parameters for fuel properties were estimated by standard methods such as density at $15^{\circ} \mathrm{C}$ by IP $131 / 57$ method, colour index by ASTM and DIN 51900 method, kinematic viscosity by viscometer $73 / 53$ method, pour point by ASTM D 97-57, IP 15/55 method, flash point by ASTM D 93-62 method, sulphur content by IP 61/59 method, water content by IP $74 / 57$ method, carbon residue by ASTM D 189-65 method, ash content by IP 4/58 method, acid value by IP $1 / 58$ method, calorific value by bomb calorimeter IP 12/58, cetane number by ASTM-D 613-86, fire point by IP 35/42 and cloud point by ASTM-D 2500 methods.

\section{Results and discussion}

\section{Physicochemical properties of neem seed oil}

After extraction of oil from neem seeds, the physicochemical properties of the oil were determined according to the standard procedure. Table I. shows the properties of the neem seed oil.

\section{FTIR analysis of crude neem oil}

To determine the functional group of extracted neem seed oil, FTIR spectroscopic analysis was employed (Fig. 1.). Appropriate quantities of $\mathrm{KBr}$ and neem seed oil (in the ratio of 100:0.1) were mixed by grinding in an agate mortar and pellets were made with about $100 \mathrm{mg}$ mixture. FTIR spectra were recorded with FTIR 8400S Shimadzu spectrophotometer in the range of $4000-400 \mathrm{~cm}^{-1}$. Resolution was kept at $2 \mathrm{~cm}^{-1}$ and the no. of scans were 30 . The major peaks are in the region of $1743.65 \mathrm{~cm}^{-1}$ and $2924.09 \mathrm{~cm}^{-1}$. FTIR spectroscopic analysis shows that the main functional groups of neem oil are carboxylic acid $(\mathrm{C}=\mathrm{O})$ appears as main 
Table I. Physicochemical properties of neem oil

\begin{tabular}{|c|c|c|}
\hline Name of analysis & Standard method & Result \\
\hline Density at $15^{\circ} \mathrm{C}, \mathrm{g} / \mathrm{cc}$ & IP-160/57 & 0.93 \\
\hline $\begin{array}{l}\text { Kinematic viscosity } \\
40^{\circ} \mathrm{C}, \mathrm{cSt}\end{array}$ & ASTM-D 445-65 & 40.7512 \\
\hline $\begin{array}{l}\text { Kinematic viscosity } \\
100^{\circ} \mathrm{C}, \mathrm{cSt}\end{array}$ & ASTM-D 445-65 & 8.608 \\
\hline Acid value, mg KOH/g & ASTM-D 664 & 28.64 \\
\hline Carbon residue $\%$ & ASTM-D 189-65 & 4.3 \\
\hline Ash content, $\%(\mathrm{w} / \mathrm{w})$ & ASTM-D 482-63 & 0.12 \\
\hline Water content,\%(v/v) & IP-74/57 & Nil \\
\hline Flash point, ${ }^{\circ} \mathrm{C}$ & ASTM-D 93-62 & 54 \\
\hline Fire point,${ }^{\circ} \mathrm{C}$ & ASTM-D 92 & 60 \\
\hline Pour point, ${ }^{\circ} \mathrm{C}$ & ASTM-D 97-57 & -12 \\
\hline Cloud point, ${ }^{\circ} \mathrm{C}$ & ASTM-D 2500 & -8 \\
\hline Color index & ASTM-D 1500 & 4.7 \\
\hline API gravity & ASTM-D 613-86 & 20.65 \\
\hline Calorific Value, MJ/kg & ASTM-D 240 & 39.501 \\
\hline Sulfur content, $\%$ & ASTM-D 129-64 & 0.18 \\
\hline Cetane number & ASTM-D 613-86 & - \\
\hline
\end{tabular}

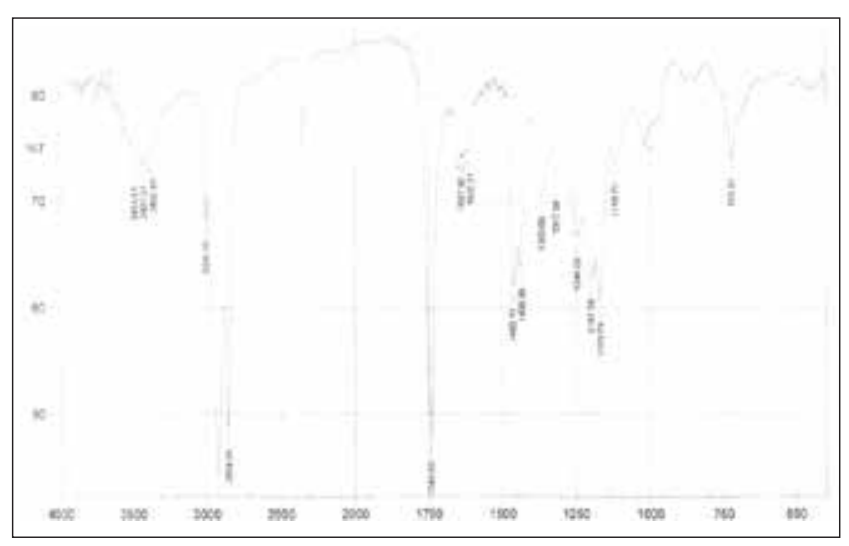

Fig. 1. FTIR analysis of crude neem oil

peak in $1743.65 \mathrm{~cm}^{-1}$ region and alkanes $(\mathrm{C}-\mathrm{H})$ that appears in 1462.04-2924.09 $\mathrm{cm}^{-1}$ (Table II)
Table II. Analysis of peak obtained in FTIR of neem seed oil

\begin{tabular}{lcl}
\hline Wave number $\mathrm{cm}^{-1}$ & Transmittance (\%) & Functional group \\
\hline 723.31 & 57.952 & $\begin{array}{l}\text { C-H aromatic bending } \\
\text { vibration }\end{array}$ \\
1165 & 48.382 & $\begin{array}{l}\text { C-O stretching vibration of } \\
\text { alcohol }\end{array}$ \\
1377.17 & 54.698 & $\begin{array}{l}\text { C-O-H bending vibration of } \\
\text { alcohol }\end{array}$ \\
1462.04 & 49.045 & $\begin{array}{l}\text { C-H bending vibration of } \\
\left.\text { alkanes (- } \mathrm{CH}_{2}-\right)\end{array}$ \\
1645.28 & 57.567 & $\begin{array}{l}\text { C-H bending vibration of } \\
\left.\text { alkenes (= } \mathrm{CH}_{2}\right)\end{array}$ \\
1743.65 & 43.259 & $\begin{array}{l}\text { C=O stretching vibration of } \\
\text { esters }\end{array}$ \\
& 41.875 & $\begin{array}{l}\text { C-H stretching vibration of } \\
\text { alkanes }\end{array}$ \\
& &
\end{tabular}

Process variables in trans esterification

Effect of temperature on yield of biodiesel

For the optimization of temperature, the percentage of catalyst and methanol was considered constant and the temperature was varied as shown in Fig. 2. The graph shows that as the temperature increases, production of biodiesel increases. Maximum (98\%) production of biodiesel occurs at

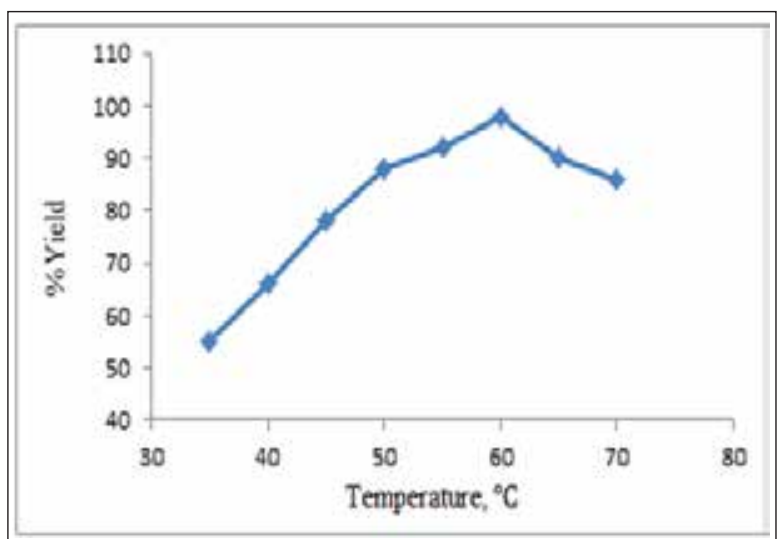

Fig. 2. Effect of temperature on the yield of biodiesel 
$60^{\circ} \mathrm{C}$ which is near boiling temperature of methanol. Further increase in temperature causes reduction of biodiesel production since boiling of methanol commenced and biodiesel separated from the system.

\section{Effect of variation of methanol on the yield of biodiesel}

The effect of change of molar ratio of methanol to oil was optimized. The amount of the catalyst $\mathrm{NaOH}$ was kept constant at $1 \%$ of the oil. The temperature was fixed at $60^{\circ} \mathrm{C}$.

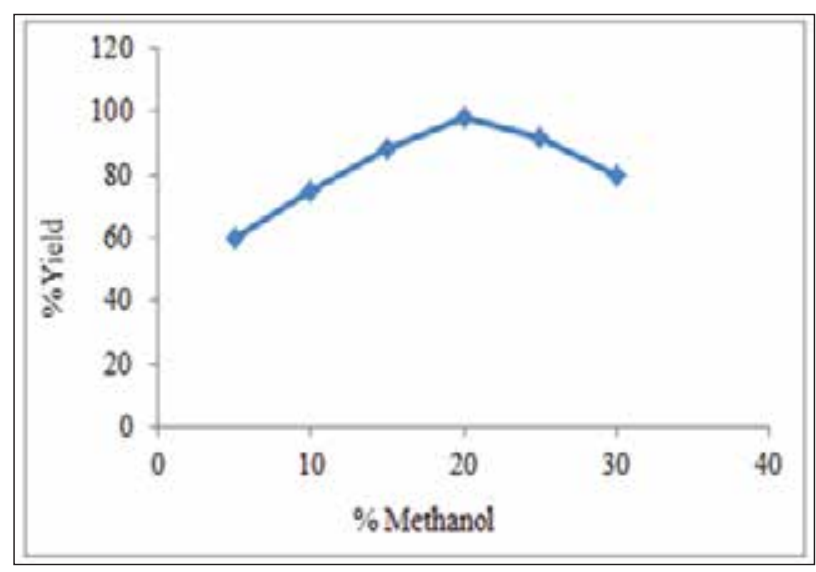

Fig. 3. Effect of methanol on the yield of biodiesel

Under this condition the percentage of methanol was varied to get maximum yield of bio- diesel (shown in Fig. 3). As the percentage of methanol increases, production of biodiesel increases. Maximum (98\%) production of biodiesel occurs for $(20 \%)$ of methanol. Further increase in percentage of methanol causes reduction of biodiesel production.

\section{Effect of variation of catalyst on yield of biodiesel}

To optimize the amount of $\mathrm{NaOH}$, the percentage of methanol was maintained constant at $20 \%$ on the wt $\%$ of oil

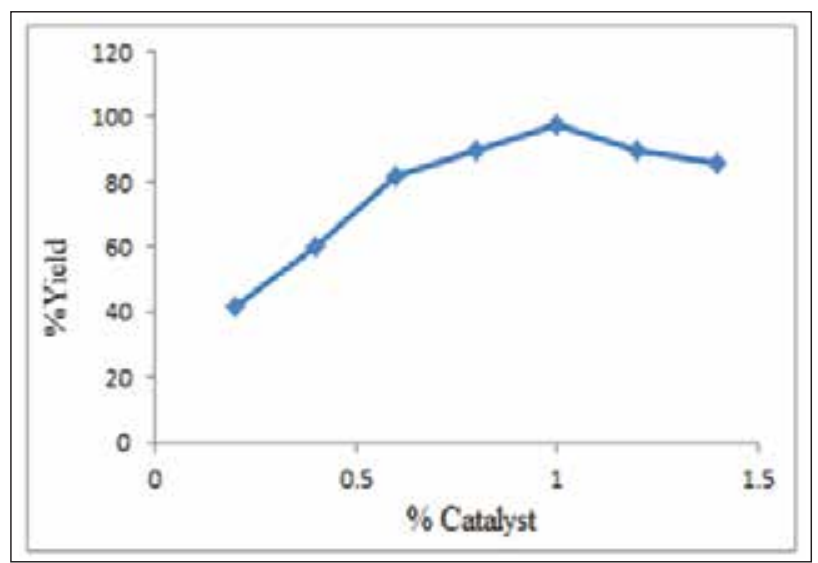

Fig. 4. Effect of variation of catalyst on the yield of biodiesel taken. The temperature was also kept constant. In this condition, the reaction were carried out with $\mathrm{NaOH}$ catalyst at concentrations $0.20,0.40,0.60,0.80,1.00$, 1.20 and $1.40 \%$ in order to determine optimum condition for the biodiesel production from the oil. The maximum yield of biodiesel was found to be at $1.00 \% \mathrm{NaOH}$ concentration as shown in Fig. 4.

\section{Effect of reaction time on yield of biodiesel}

All variables except reaction time were kept constant in their optimum value. The tran sesterification reaction was continued for different period of time such as 30,60, 90 and $120 \mathrm{~min}$ respectively to yield the product. The result of this optimization is shown in (Fig. 5). It is found that with the increase of duration of reaction, the yield of biodiesel was enhanced. Maximum yield (about $98 \%$ ) was obtained in 90 mins.

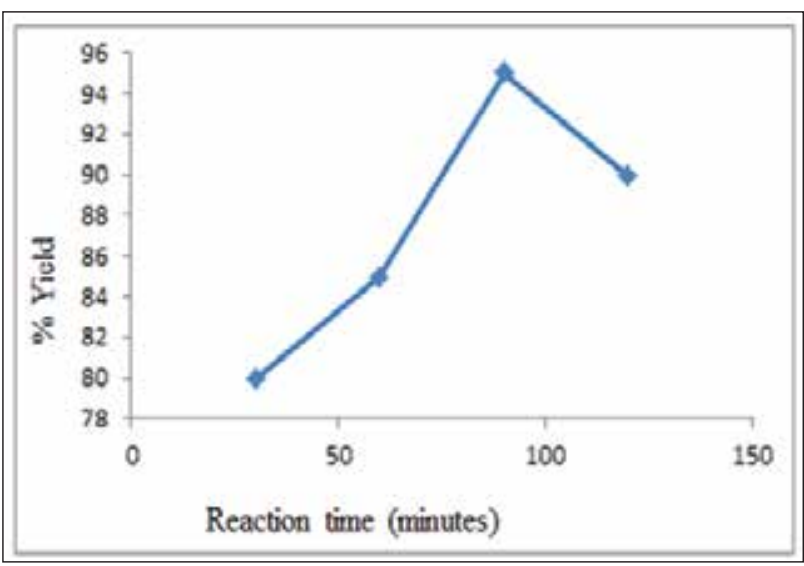

Fig. 5. Effect of reaction time on the yield of biodiesel

\section{Analysis of peak obtained in FTIR spectra of biodiesel}

To determine the functional group of neem seed oil biodiesel, FTIR spectroscopic analysis was performed following the procedure identical to that for the oil. FTIR spectrum shown in Fig. 6 reveals that the major peaks are in the region of $1460.11 \mathrm{~cm}^{-1}$ and $2926.01 \mathrm{~cm}^{-1}$ and the main functional groups of neem biodiesel are carboxylic acid $(\mathrm{C}=\mathrm{O})$ showing bands as the main peak in $1743.65 \mathrm{~cm}^{-1}$ region and alkanes $(\mathrm{C}-\mathrm{H})$ in the region of $1460.11-2854.65$ and $2926.01 \mathrm{~cm}^{-1}$ (Table III). The main functional groups of produced biodiesel are carboxylic acid $(\mathrm{C}=\mathrm{O})$ showing the main peak in $1743.65 \mathrm{~cm}^{-1}$ region and alkanes $(\mathrm{C}-\mathrm{H})$ in the 1460.11-2926.01 range (Table III). 


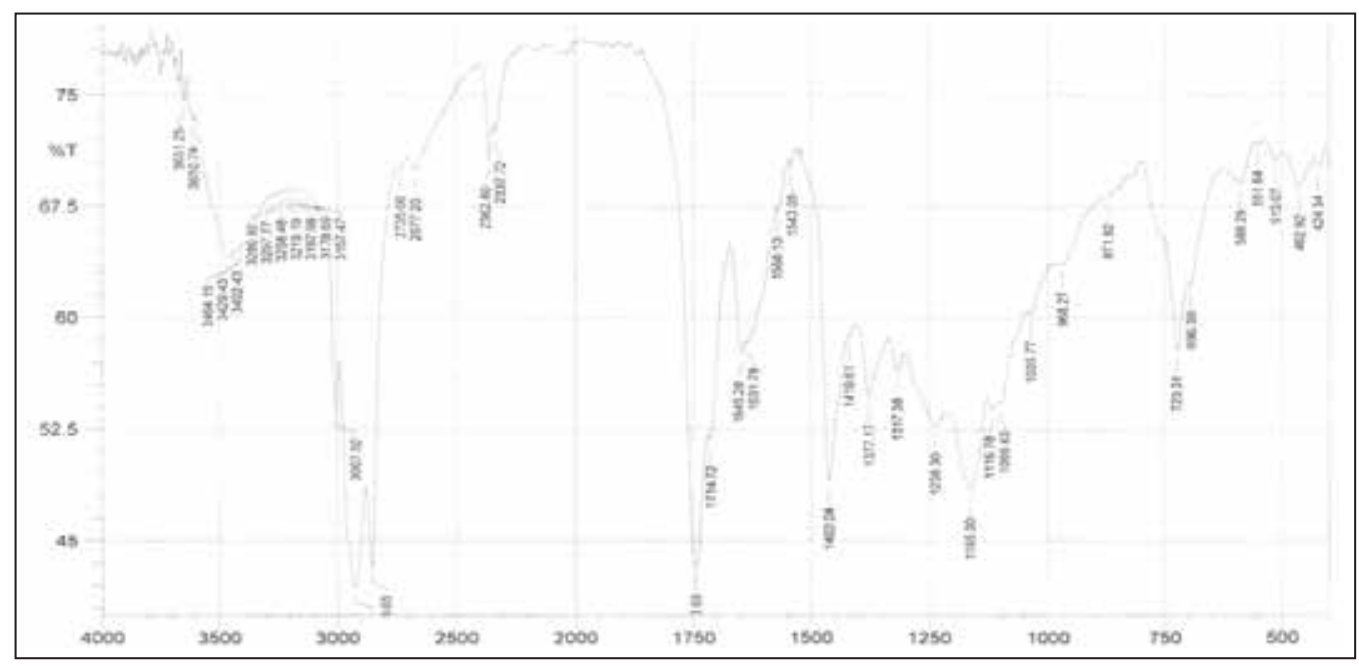

Fig. 6. FTIR analysis of biodiesel

Table III. Analysis of bands obtained in FTIR spectra of biodiesel

\begin{tabular}{|c|c|c|}
\hline Wave number $\mathrm{cm}^{-1}$ & Transmittance $(\%)$ & Functional group \\
\hline 723.31 & 74.217 & $\begin{array}{l}\mathrm{C}-\mathrm{H} \text { aromatic bending } \\
\text { vibration }\end{array}$ \\
\hline 1170.79 & 60.595 & $\begin{array}{l}\mathrm{C}=\mathrm{O} \text { stretching vibration of } \\
\text { alcohol }\end{array}$ \\
\hline 1365.6 & 70.53 & $\begin{array}{l}\mathrm{C}-\mathrm{O}-\mathrm{H} \text { bending vibration of } \\
\text { alcohol }\end{array}$ \\
\hline 1460.11 & 61.932 & $\begin{array}{l}\mathrm{C}-\mathrm{H} \text { bending vibration of } \\
\text { alkanes }\left(-\mathrm{CH}_{2-}\right)\end{array}$ \\
\hline 2854.65 & 48.664 & $\begin{array}{l}\mathrm{C}-\mathrm{H} \text { stretching vibration of } \\
\text { alkanes }\left(-\mathrm{CH}_{2-}\right)\end{array}$ \\
\hline 1743.65 & 47.451 & $\begin{array}{l}\mathrm{C}=\mathrm{O} \text { stretching vibration of } \\
\text { esters }\end{array}$ \\
\hline 2926.01 & 44.32 & $\begin{array}{l}\mathrm{C}-\mathrm{H} \text { stretching vibration of } \\
\text { alkanes }\end{array}$ \\
\hline 3454.51 & 73.753 & O-H (hydrogen bonded) \\
\hline
\end{tabular}

\section{Optimum condition of biodiesel production from neem oil}

The optimum conditions for biodiesel production from neem seed oil can be summarized as follows: The overall trans esterification reaction requires about $20 \%$ of methanol on the basis oil taken; catalyst $(\mathrm{NaOH})$ with a concentration is $1.0 \%$ of the oil and a reaction time of 90 mins. at a temperature of $60^{\circ} \mathrm{C}$ with moderate stirring rate. The optimum yield is $98 \%$.

\section{Characteristics of neem biodiesel}

The biodiesel obtained was then characterized by the standard methods. Table IV describes the fuel characteristics of biodiesel from neem seed oil and also gives a comparison of obtained biodiesel with conventional diesel fuel.

\section{Engine performance study}

Produced biodiesel (Neem Methyl Ester: NME) was blended with diesel in different proportions and engine performance study was done. Engine specification was such as Engine type: 4- stroke CI engine, number of cylinder: one and compression ratio: 16.5 .

\section{Speed optimization}

Fig. 7 illustrates the variation of brake thermal efficiency with engine speed at load $55.6 \mathrm{~N}$ with diesel. From Fig.7 it is apparent that the brake thermal efficiency of engine increases with increase in engine speed. After reaching the maximum value, the efficiency of the engine also decreases. This is due to the fact that, initially with the increase of engine speed the torque produced by the engine increases, hence the efficiency also increases. But at higher rpm (>900) more amount of fuel is injected into the engine cylinder per cycle and due to higher engine speed these fuel doesn't get sufficient time to burn completely which reduce the efficiency of the engine. Hence the optimum speed was $900 \mathrm{rpm}$. 
Table -IV Comparison of produced biodiesel with standard and commercial diesel

\begin{tabular}{|c|c|c|c|c|}
\hline Parameter & $\begin{array}{l}\text { Standard } \\
\text { method }\end{array}$ & $\begin{array}{l}\text { Biodiesel } \\
\text { standard } \\
(\mathrm{ASTM})\end{array}$ & $\begin{array}{l}\text { Neem } \\
\text { biodiesel }\end{array}$ & $\begin{array}{l}\text { Commercial } \\
\text { diesel (ASTM) }\end{array}$ \\
\hline $\begin{array}{l}\text { Density at } 15^{\circ} \mathrm{C}, \\
\mathrm{gm} / \mathrm{cc}\end{array}$ & IP - 160/57 & 0.88 & 0.875 & 0.8445 \\
\hline Kinematic & ASTM -D & $1.9-6.0$ & 6.17 & 2.71 \\
\hline $\begin{array}{l}\text { Viscosity at } \\
40^{\circ} \mathrm{C}, \mathrm{cSt}\end{array}$ & $445-65$ & & & \\
\hline $\begin{array}{l}\text { Acid value, mg } \\
\mathrm{KOH} / \mathrm{g}\end{array}$ & $\begin{array}{l}\text { ASTM -D } \\
664\end{array}$ & $0.80 \max$ & 0.8716 & 0.34 \\
\hline $\begin{array}{l}\text { Carbon } r \text { esidue } \% \\
(\mathrm{w} / \mathrm{w})\end{array}$ & $\begin{array}{l}\text { ASTM -D } \\
189-65\end{array}$ & $0.05 \max$ & 0.75 & 0.05 \\
\hline $\begin{array}{l}\text { Ash content, } \% \\
(\mathrm{w} / \mathrm{w})\end{array}$ & $\begin{array}{l}\text { ASTM -D } \\
482-63\end{array}$ & $0.02 \max$ & 0.006 & 0.02 \\
\hline Water c ontent, $\%$ & IP - 74/57 & 0.05 & Nil & Nil \\
\hline Flash point, ${ }^{\circ} \mathrm{C}$ & $\begin{array}{l}\text { ASTM -D } \\
93-62\end{array}$ & $100-170$ & 70 & 65 \\
\hline Pour point,${ }^{\circ} \mathrm{C}$ & $\begin{array}{l}\text { ASTM -D } \\
97-57\end{array}$ & -15 to -16 & -16 & -20 \\
\hline Cloud point, ${ }^{\circ} \mathrm{C}$ & $\begin{array}{l}\text { ASTM -D } \\
2500\end{array}$ & -3 to -12 & -12 & -12 \\
\hline API gravity & & & 30.21 & 34.52 \\
\hline $\begin{array}{l}\text { Calorific Value, } \\
\mathrm{MJ} / \mathrm{kg}\end{array}$ & $\begin{array}{l}\text { ASTM -D } \\
240\end{array}$ & 38.586 & 40.2 & 44.5 \\
\hline Sulfur content, $\%$ & $\begin{array}{l}\text { ASTM -D } \\
129-64\end{array}$ & & 0.07 & 0.905 \\
\hline Cetane number & $\begin{array}{l}\text { ASTM -D } \\
613-86\end{array}$ & $48-60$ & 53 & 51 \\
\hline
\end{tabular}




\section{Load optimization}

The engine was run at the fixed rpm (900) and brake power was varied from $0.44 \mathrm{KW}$ to $1.05 \mathrm{KW}$. Fig.8. illustrates variation of brake thermal efficiency of engine with respect to brake power. The efficiency of the engine increases with the increase in brake power. The maximum brake thermal efficiency of diesel fuel is $20.38 \%$ at brake power $0.79 \mathrm{KW}$. Higher brake thermal efficiency is due to better mixing of fuel with air which results in better combustion. At higher brake power $(>0.79 \mathrm{KW})$ more amount of fuel is injected into the engine cylinder which is not completely burnt. It causes higher BSFC and low brake thermal efficiency. Hence optimum engine load (brake power) was $0.79 \mathrm{KW}$.

\section{Brake thermal efficiency}

The variation of brake thermal efficiency with engine load using all types of fuels/blends shown in Fig. 9. Brake power was varied from $0.44 \mathrm{KW}$ to $1.05 \mathrm{KW}$. Here DF= Diesel Fuel

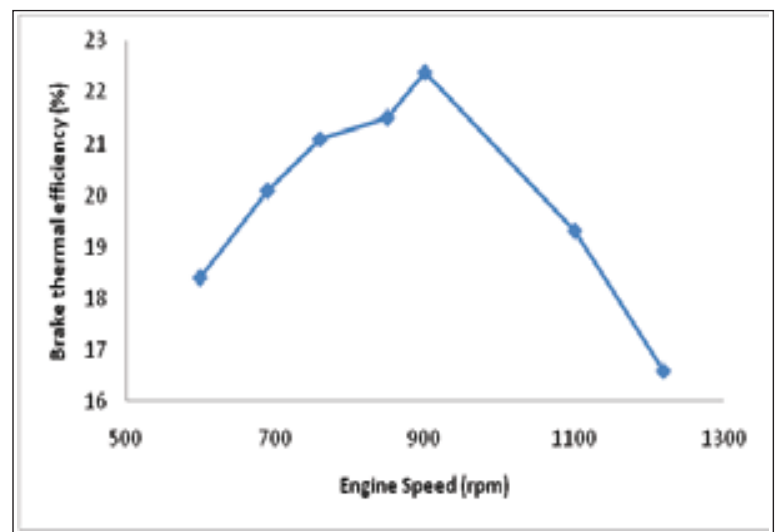

Fig. 7. Variation of brake thermal efficiency with engine speed (at load 55.6N)

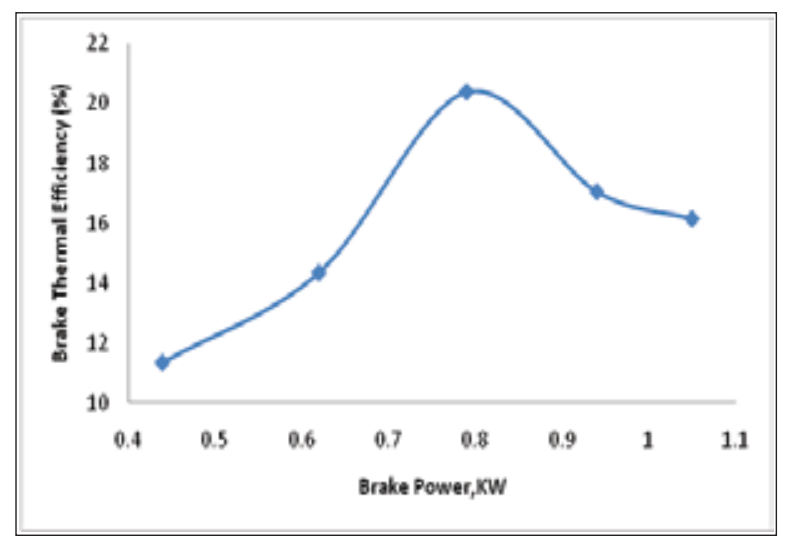

Fig. 8 .Variation of brake thermal efficiency with brake power $(900 \mathrm{rpm})$

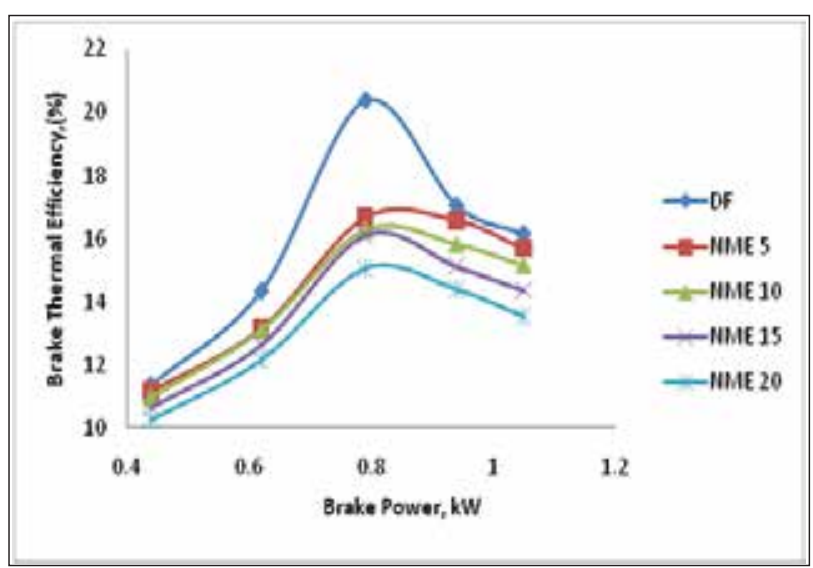

Fig. 9. Variation of brake thermal efficiency with brake power of different NME blends

and $\mathrm{NME}=$ Neem Methyl Ester. The brake thermal efficiency was calculated by the ratio of brake power to input power. The brake thermal efficiency increases with the engine load (brake power) for all fuels/ blends. The maximum value of brake thermal efficiencies with DF, NME5, NME10, NME15 and NME20 were found to be $20.38 \%, 16.67,16.28 \%, 16.10$ $\%$ and $15.06 \%$ respectively at brake power $0.79 \mathrm{KW}$

\section{Brake specific fuel consumption (BSFC)}

Fig. 10. compares the fuel consumption of diesel/ NME at various brake power in the range of $0.44 \mathrm{KW}-1.02 \mathrm{KW}$. The Fig. shows that BSFC decreases with the increase of brake power up to brake power $0.79 \mathrm{KW}$. Then the BSFC increases with the increase of brake power. The value of BFSC with

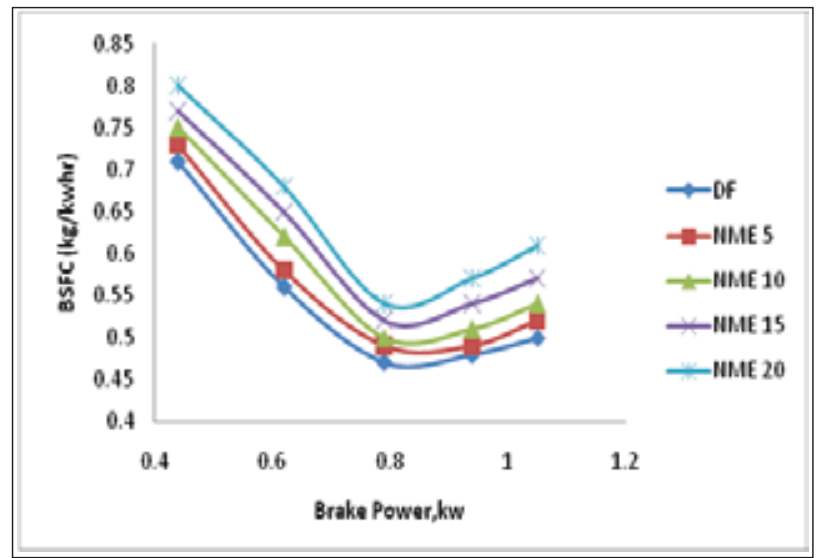

Fig. 10. Variation of brake specific fuel consumption with brake power of different NME blends 
DF, NME5, NME10, NME15 and NME20 were found to be $0.47,0.49,0.50,0.52,0.54 \mathrm{KW}-\mathrm{hr}$ respectively at brake power $0.79 \mathrm{KW}$. Among the NME blends, NME5 shows the lowest BSFC.

\section{Conclusions}

Biodiesel can be extracted from neem seed oil. The optimum condition has been $20 \%$ methanol and $1.0 \%$ $\mathrm{NaOH}$ catalyst with reaction temperature and time is $60^{\circ}$ $\mathrm{C}$ and $90 \mathrm{~min}$ respectively. The physicochemical properties of the neem biodiesel are similar to standard biodiesel. Neem biodiesel blends have been tested in a single cylinder, 4-stroke diesel engine. Brake thermal efficiency and BSFC of NME are comparable to DF. The higher brake thermal efficiency is $20.38 \%$ for $5 \%$ blend of neem methyl ester. The results reveal the possibility of neem seed oil as a potential source of biodiesel. As Bangladesh does not have petroleum resources, renewable fuel of this kind may be very helpful to solve our present fuel oil crisis.

\section{References}

Anonymous, Plunkett's automobile industry almanac (2008), Automobile, truck and specialty vehicle industry market research, statistics, trends \& leading companies, Huston (Texas), Plunkett research Ltd.

Balat M and Balat H (2009), Recent trends in global production and utilization of bioethanol fuel, App. Energy 86: 769-778. DOI. org/10.1016/ j.apenergy. 2009.03.015

Banik SK, Rouf MA, Khanam M, Islam MS, Rabeya T, Afrose F and Saha D (2015), Production of bio-diesel from Pithraj (Aphanamixis polystachya) seed oil, Bangladesh J. Sci. Ind. Res. 50(2): 135-142. DOI.org/10.3329/bjsir.v50i2.24354
Carvalho J, Ribeiro A, Castro J, Vilarinho C and Castro F (2011), Biodiesel Production By Microalgae and Macroalgae from North Littoral Portuguese Coast, $1^{\text {st }}$ International Conference, September $12^{\text {th }}-14^{\text {th }}$.

Dorain JP, Franssen HT and Smbeck DR (2006), Global challenges in energy, Energy Policy 34: 1984-1991. DOI.org/10.1016/j.enpol.2005.03.010

Goldemberg J (2008), Environmental and ecological dimensions of bio-fuels, Int. Conference on the ecological dimensions of bio-fuels, Washington (DC).

Hemant Y, Shrirame NL, Panwar BR and Bamniya (2011), Bio diesel from castor oil - A green energy option, Low Carbon Economy 2: 1-6. DOI:10.4236/lce.2011.21001

Kaura SK, Gupta SK and Chowdhury JB (1998), Morphological and oil content variation in seeds of Azadirachta indica A. Juss. (Neem) from northern and western provenances of India, Plant Foods for Human Nutrition 52: 293-298.

Sylvester C Izah, Elijah I and Ohimain (2013), The challenge of biodiesel production from oil palm feedstock in Nigeria, Greener Journal of Biological Sciences ISSN: 2276-7762 3(1): 1-12.

Wstermann P, Jorgensen B, Lange L, Ahring BK and Christensen CH (2007), Maximizing renewable hydrogen production from biomass in a bio/catalytic refinery, Int. J. Hydrogen Energy 32: 4135-4141. DOI.org/10.1016/j.ijhydene.2007.06.018

Wilson P (2010), Biodiesel production from Jatropha curcas: A review, Scientific Research and Essays. 5(14): 1796-1808. 